\title{
Continuing education and its interfaces with ambulatory care sensitive conditions*
}

\author{
Educação permanente e suas interfaces com as condições sensíveis à atenção primária
}

Charlene Ester Machado Silva ${ }^{1}$, Denise Barbosa de Castro Friedrich ${ }^{1}$, Beatriz Francisco Farah ${ }^{1}$, Kênia Lara Silva $^{2}$

Objective: to understand the process of continuing education by primary health care nurses and their interfaces with ambulatory care sensitive conditions. Methods: a qualitative study was carried out with 14 nurses from health units. To collect the data, we used semi-structured interviews and the analysis was carried out through dialectical hermeneutics. Results: two categories emerged: Assistance in primary health care and hospital admissions - which pointed out that the major cause of hospitalizations is related to chronic diseases, and that most of them were preventable; Education: a tool to deal with ambulatory care sensitive conditions where continuing education is recognized as a tool to interfere in the occurrence of these hospitalizations, but the practices carried out are closer to continuing education. Conclusion: nurses have developed educational processes that are closer to continuing education. The relationship between continuing education and ambulatory care sensitive conditions is still incipient.

Descriptors: Primary Health Care; Education, Continuing; Education, Nursing; Hospitalization.

Objetivo: compreender o processo de educação permanente realizado pelos enfermeiros da atenção primária à saúde e suas interfaces com as condições sensíveis à atenção primária. Métodos: estudo qualitativo, realizado com 14 enfermeiros de unidades de saúde. Para captação dos dados, utilizou-se entrevista semiestruturada e análise por meio da hermenêutica dialética. Resultados: emergiram duas categorias: Assistência na atenção primária à saúde e internações hospitalares - apontou que a maior causa de internações está relacionada a doenças crônicas, e que grande parte delas poderia ser evitada; Educação: ferramenta para lidar com as condições sensíveis à atenção primária - a educação permanente é reconhecida como ferramenta para interferir na ocorrência dessas hospitalizações, porém as práticas realizadas aproximam-se mais da educação continuada. Conclusão: os enfermeiros desenvolvem processos educativos que se aproximam mais da educação continuada. A relação entre educação permanente e condições sensíveis a atenção primária ainda é incipiente.

Descritores: Atenção Primária à Saúde; Educação Continuada; Educação em Enfermagem; Hospitalização.

\footnotetext{
*Excerpted from the dissertation "Educação permanente e suas interfaces com as condições sensíveis à atenção primária”, Universidade Federal de Juiz de Fora, 2016.

${ }^{1}$ Universidade Federal de Juiz de Fora. Juiz de Fora, MG, Brazil.

${ }^{2}$ Universidade Federal de Minas Gerais. Belo Horizonte, MG, Brazil.

Corresponding author: Charlene Ester Machado Silva

Av Olegário Maciel, 1.930, apto 504/bloco G. Paineiras. CEP: 36016-011. Juiz de Fora, MG, Brazil. E-mail: charlene.mg@gmail.com
} 


\section{Introduction}

Primary care in Brazil, also called basic care, has been strengthened by the health reform movement and the creation of the Unified Health System. The National Primary Care Policy covers the duties of basic health care services and among them is resolubility. Basic care should be able to meet the majority of the health needs of the population using appropriate technologies in a timely and effective manner ${ }^{(1)}$.

In this way, basic attention with ability to solve the health needs of the population could avoid that certain aggravations that can be resolved at this point in the network be referred to other levels, causing unnecessary overloading. Those conditions for which adequate care and management of acute episodes and preventive care and health promotion could prevent or reduce hospitalizations are called ambulatory care sensitive conditions ${ }^{(2)}$.

In the context of primary care, the National Primary Care Policy also deals with continuing education, stating that this process, besides boosting the qualification, acquisition of knowledge and skills of professionals, should also be the guiding principle of a learning that arises from the daily life of the process at this level of attention ${ }^{(1)}$.

Thus, continuing education can be understood as a problematizing practice that starts from the daily routine of work, leading to reflection on the actions that have been carried out on a daily basis, which can generate a new way of acting and doing and bring about improvements in the way of work and care production ${ }^{(3)}$. Continuing education, therefore, integrates the teaching-learning process into the daily life of services, contextualizing the practices developed and problematizing the experiences witnessed ${ }^{(4)}$. This idea goes against the ideology of continuing education that refers to the continuity of the traditional school model with a focus on updating knowledge using transmission techniques. Continuing education is normally developed in form of courses and periodic training, focusing on the professional categories and practically disregarding the notion of team work ${ }^{(4)}$.

In view of the above, the role of primary care is considered fundamental for the organization of care networks, to make it resolutive and to advance in the management and coordination of care for users ${ }^{(1)}$. Continuing education emerges as one of the tools to assist professionals in dealing with ambulatory care sensitive conditions. Nurses are inserted in this context as professionals engaged in primary care, in relation to the provision of care and the management and development of continuing education aimed at their teams. The objective of this study is to understand the process of continuing education performed by primary health care nurses and their interfaces with ambulatory care sensitive conditions.

\section{Methods}

This is a qualitative research. The qualitative method works with values, beliefs, representations, habits, attitudes and opinions and is concerned with achieving a deeper and more subjective understanding of the research object ${ }^{(5)}$. The dialectical hermeneutics was used, not fundamentally as a theoretical reference for data collection, but especially, as a contribution to data analysis and treatment.

Hermeneutics refers to the interpretive art or method that seeks to understand a particular text, which is considered in its broad sense. For this understanding, it seeks to investigate the different elements that make up the hermeneutic process as the author, the reader and the text itself. Dialectics, in the methodological perspective, must provide instruments for criticism and apprehension of contradictions of language, understanding that the analysis of meanings must deal with social practices ${ }^{(5)}$.

The scenario of this study was a municipality in the Atlantic forest region of Minas Gerais. A total of 14 nurses working in the primary health care units with and without family health strategy were recruited through an individual invitation and formal acceptance to participate in the study. They were identified 
with codes, I1 through I14, following the order of the interview.

Data collection took place in the period from January to March 2016. To this end, a semi-structured interview was conducted with a script composed of an initial part for characterization of the participants and by open questions based on the following guiding theme: how do continuing education processes occur in order to aid nurses to act in a way to reduce the hospitalizations due to ambulatory care sensitive conditions? This inquiry made it possible for the participants to discuss the research object.

Interviews were previously scheduled and conducted in individually basis in the primary health care units. They were recorded on digital equipment after the consent of the participants in order not to lose information. The duration of the interviews ranged from 14 minutes and 56 seconds to 33 minutes and one second. The average duration was 19 minutes, totaling four hours, 27 minutes and 27 seconds of recording.

Data were treated with the contribution of the dialectical hermeneutics ${ }^{(5)}$ following a few steps, namely: a) data ordering - by means of the transcription of recorded testimonies, re-reading of the material and organization of the reports; b) data classification - when an exhaustive and repeated reading of the testimonies was done, reading each body with the excerpt of registration units and sorting of classification according to the most important expressions; c) final analysis - made according to the objectives of the study.

In the process of data classification, a table containing the identified nuclei of meaning was created, namely: more frequent hospitalizations in the area covered by the unit; preventable character of hospitalizations; assistance to users so that they do not need hospitalization; ambulatory care sensitive conditions; needs of educational processes most demanded by the team and verification of how these processes have been developed; and educational processes as a tool to help reducing hospitalizations due to ambulatory care sensitive conditions.
After preparing the table and reading, data were treated through horizontal and vertical synthesis. The first allowed the reading of each category of all interviews, providing an overview of similarities, divergences, complementarities of each nucleus of meaning, and the vertical synthesis allowed a broad view of each interview and of the ideas of each interviewee about the study object. Then, a transversal reading of the nuclei of meaning was made through the comparison of the speeches of the 14 participants, aligned with the guiding question, the research objectives, and the theoretical reference of the study. This reading enabled the construction of the categories: 1) Assistance in Primary Health Care and hospital admissions; 2nd) Education: a tool to deal with ambulatory care sensitive conditions.

The study complied with the formal requirements contained in the national and international regulatory standards for research involving human beings.

\section{Results}

From 14 nurses who participated in the research, ten work in primary health care units with family health strategy and three in units without this strategy. The female sex was predominant among the participants; there were 12 women and two men. With regard to age, six professionals were in the age group between 26-35 years; three in the age group of 36-45; three in the age group of 46-55; and two in the age group of 56-65. As for the time elapsed since graduation, this was very variable, and varied from two to 34 years; the majority, eight professionals, had ten or more years of experience after completing the undergraduate training.

Regarding primary care, four professionals had worked for less than five years in this level of attention, four had worked for between five and ten years, five between 11 and 20 years, and one professional had worked for more than 21 years. With regard to professional training, 12 nurses had postgraduate 
degrees, and among them, half had more than one specialization. There were eight nurses specialized in family health, of which seven were specialized in sensu lato and one in the medical residency. Two had master degree: one in Nursing and another in Collective Health. The two categories constructed from the results are presented below.

\section{Assistance in primary health care and hospital admissions}

When talking about ambulatory care sensitive conditions, the participants cited conditions such as diabetes, hypertension, mental health, tuberculosis, teenage pregnancy. In addition to these chronic diseases ... the mental health are much more frequent issues (I9).

In the statements of the participants about the most frequent hospitalizations in their areas of coverage, the most common causes are those related to stroke, diabetes complications, mental health, children with respiratory problems, childbirth, surgeries, infarction, complicated hypertension, cancer, diabetic foot, pregnant woman with urinary infection or other injuries during pregnancy. The most frequent hospitalization happen for childbirth... stroke is also a cause for hospitalization... we have cases of hospitalizations due to poor circulation, infarction. And also because of mental issues... but, more often, it is because of complications from diabetes and hypertension (I7).

Regarding the preventable nature of the hospitalizations, the interviewees pointed out that those caused by complications of chronic diseases could be avoided with follow-up of the team, prioritizing educational activities; guidance to users; raise of awareness and action among the population, highlighting the importance of user adherence. It may work, yes, mainly in the case of diseases where you can get good control, because there are drugs available for treatment, and a trained professional to provide assistance, the unit to host them. But most will depend on the patients, on their adherence to the treatment (I4).

While describing the assistance provided to users in the coverage area to avoid their hospitalization, the respondents cited typical Primary Care actions such as: medical and nursing consultations, groups, vaccination, scheduled consultations and spontaneous demand, specialized consultation, consultation scheduled according to the primary care guidelines, risk stratification for scheduling consultations, home visits to bedridden users, health consultancies based on life cycles, programs aimed at diabetic users, childcare, pregnancy, hosting, among others. What we do here is groups, individual consultation with a doctor and a nurse, that's what we do, that's what we work for and guidance, a lot of guidance from all professionals (I7).

Nurses from health units that do not have the family health strategy report greater difficulty in developing actions typical of this level of care. Because this is a unit that does not have family health strategy, it becomes more complicated, but we work scheduling services and responding to spontaneous demand as well. There are specialists in service, a gynecologist and a pediatrician and also a general practitioner (I4).

\section{Education: a tool to deal with ambulatory care sensitive conditions}

According to the horizontal synthesis, the interviewees mentioned that the educational process is important, since it makes professionals more confident to act, but they emphasized that they would need more time and personnel to carry out an efficient educational process. They recognize that the whole team demands diverse educational processes. Continuing education is important for sure, it should be done, the needs are real (I12).

About how and when they provide these processes, the interviewees cited the team meeting, which is regulated by the Municipal Health Department and held every Thursday as a time they have to discuss and work the needs of the team. They also use these opportune moments to develop continuing education. Every Thursday we gather for the team meeting and then we discuss the issues that each one raised at that meeting. The unit closes for the public, it gets easier there. But whenever it is necessary, we clarify some points, some situations not necessarily only on that day (I3). Although they report that this is not the only 
moment they have continuing education and that they meet the demands of the team as they arise, there is no specific timetable for continuing education on the teams' agenda. And this is due to several factors pointed out by them, including the absence of time, the lack of professionals in the teams, and the excessive demand of service. I think we would need more time, enough people in the teams so that we can better accomplish these educational processes (I5).

Among the most cited needs for continuing education are updates of immunization techniques and schedule, flows within the system to meet the needs of patients, annotations in medical records, hosting, women's health, home visits, interpersonal relationships and family approach. Among all the issues is the question of relationship, to discuss the relationship between teams and also with people [13]. So I think we should sit down with the technicians, talk, transmit the changes, the updates... also talk about the record in the files, which is very important and sometimes the technicians do not do those notes... with the agents, are those topics are related to vaccination... Sometimes it's important to address these topics in the users' homes (I6).

Some speeches allow us to understand what are the issues are most frequently addressed by nurses before the demands of the teams and how they make this approach. I try, in the meetings with the team, to talk about it, sometimes to separate into themes, right, we discuss them with time,... for example, vaccine update, always trying to establish a dialogue, right, an exchange of experiences which is the richest way for us to work... sometimes we have the calls from the Health Department in which there are trainings on specific topics, but it is in that format of classes, well, quite traditional (I14).

When talking about the educational process as an auxiliary tool to reduce hospitalizations due to ambulatory care sensitive conditions, the interviewees considered the educational processes as important for reducing hospitalizations, as they leave the team more confident to deal with the common situations of the working routine. Yes, I consider it important because... for example, last year we had a training on Hiperdia. I participated, the physicians also participated and I found it very interesting because we learned a different way of approaching patients, completely different from how we had been doing. That is good for me (I8). When professionals are more qualified and updated they feel more confident, they look at things from a broader perspective, perceiving things that would otherwise go unnoticed. So, I think that yes, the times I was present in some type of training, in which I learned a new topic I came back with a new approach towards specific users (I14).

\section{Discussion}

The lack of studies articulating the themes of continuing education and ambulatory care sensitive conditions can be pointed out as a limitation for interpretation of the results. It is also important to consider the potential for generalization of the results, because the research was carried out in a municipality in the Atlantic forest region of Minas Gerais with some nurses working in the primary care network. The study reflects, therefore, the reality experienced by these nurses during the data collection, and the results can undergo variations due to changes in this context. However, the results reinforce the importance of continuing education in the training of professionals and its applicability as a potential tool to intervene in the occurrence of ambulatory care sensitive conditions. They can also serve as support to plan health actions aimed at improving the quality of primary care in the studied municipality and in municipalities with similar characteristics.

Among the reasons that most lead hospitalizations of users of the areas covered by the studied units that appear in the Brazilian List of Hospitalizations for ambulatory care sensitive conditions are cerebrovascular diseases, which is in the group 12 on cerebrovascular diseases; respiratory diseases, in the groups six and seven; complications of gestation in the group 19 of prenatal and childbirth-related diseases; and complications from diabetes in the extensive group 13, which encompasses 25 diagnoses of the Tenth International Classification of Diseases ${ }^{(6)}$. Knowledge about the most prevalent ambulatory care sensitive 
conditions in the covered area is important because it allows reflection on the use of care management tools such as clinical protocols and unique therapeutic projects in the management of more complex cases $^{(7)}$.

Most of the conditions indicated by the interviewees as reasons for hospitalization in their covered area were related to ambulatory care sensitive conditions. This is, in general, in line with the findings of a study carried out in the same municipality where the present research was developed. The study analyzed the most frequent causes of hospitalizations due to ambulatory care sensitive conditions in the years 2002 to 2005 and 2006 to 2009 and pointed out that these causes are related to heart failure, cerebrovascular diseases, angina pectoris, pulmonary diseases, urinary tract infections and gastroenteritis ${ }^{(8)}$.

A reduction in the general hospitalization rates for ambulatory care sensitive conditions has been noticed in Brazil ${ }^{(9)}$ and in the State of Minas Gerais. However, the municipality in question goes in the opposite direction to these results, since there was an increase in hospitalizations due to ambulatory care sensitive conditions ${ }^{(10)}$.

The interviewees indicated the preventable nature of hospitalizations, especially those whose causes are related to ambulatory care sensitive conditions, in places where primary care is provided is a resolute manner and a way that meets the users' health demands. In this sense, a series of actions such as health education, follow-up of diseases, improved adherence to treatment, and continuity of care can contribute to the goal of reducing hospitalizations due to avoidable causes, which it would improve quality of care and reduce health expenses ${ }^{(11)}$.

Regarding the care provided to users in the covered area in order to meet sensitive conditions, the participants cited typical actions of primary care in their speeches, as for example, actions of risk stratification in the case of hypertension, and programs for care of diabetic patients, as well as children and pregnant women, and pointed out the attendance to diseases that are part of primary care programmatic actions. The development of actions such as nursing consultations, home visits, educational activities, hosting, and administrative activities is part of the care practices developed by nurses in basic care ${ }^{(12)}$. These activities were also verified in the discourse of nurses participating in the present study.

It is noted that the assistance provided by the primary health care units without family health strategy is still focused on the biomedical model. There are reports in the literature about the relationship between the expansion of coverage and access to primary care and the expansion of family health teams with the reduction of hospitalizations due to ambulatory care sensitive conditions ${ }^{(13)}$. However, there are also reports that do not confirm such a correlation between the expansion of the family health strategy and the reduction of hospitalizations due to sensitive conditions $^{(10)}$. Primary Care plays a prominent role in reducing hospitalizations for chronic diseases, as well as for ambulatory care sensitive conditions. The strengthening of care actions at this level in the care network and the relationship between professionals and users are very important to actually prevent hospitalizations due to ambulatory care sensitive conditions $^{(14)}$.

The interviewees evidently had different notions of what is continuing education. They understand it as updates, training, educational processes, and so forth. For the development of educational processes, they mentioned team meetings as an opportunity to discuss some demands, but this moment is firstly intended to bureaucratic issues, to transfer information provided by the Municipal Health Department. The demand for services mostly focused on the curative model of care and on the large number of duties assumed by nurses, which include those of assistive and administrative nature, interferes with and compromises the realization of continuing education ${ }^{(15)}$.

Regarding the topics most addressed by nurses with their teams, a strong focus on the issue of vacci- 
nes can be highlighted, encompassing techniques and especially updates of the vaccination schedule. This theme is in the group one of the ambulatory care sensitive conditions, which is related to diseases prevented by immunization ${ }^{(6)}$. There is then a movement towards the articulation between continuing education and ambulatory care sensitive conditions.

Chronic diseases are the ones that most affect the population of the studied municipality and represent the most frequent cause of hospitalizations due to ambulatory care sensitive conditions ${ }^{(16)}$. Regarding chronic conditions, it has been pointed out that family health strategy teams must rely on prevention strategies directed at the main risk factors related to behaviors and lifestyles ${ }^{(17)}$. Continuing education should, therefore, favor the adequate care of chronic conditions and ambulatory care sensitive conditions. Such an approach would instill the attention of professionals to the occurrence of these conditions and would lead them to reflect on ways of addressing them properly. To achieve this goal tough, it is necessary that the organization of municipal health policies and the work process in primary care be in line with the model of health promotion.

The mastery of technical knowledge of the profession is valued by nurses because it boosts confidence when dealing with users in the planning and execution of actions and procedures. Moreover, it establishes a relationship of trust and appreciation with other professionals, since they believe that technical competence makes them a reference within the team $^{(18)}$.

On the other hand, it is evident that the working world is a permanent school of training processes based on the experience of a group of workers and their needs to update the practice. This process of training differs from continuing education, which starts from prefabricated knowledge specifically used to prepare the learner for an action, and approaches the production of a new knowledge or update of an existing knowledge through the formative action of those involved in the process ${ }^{(19)}$.
Education, therefore, has as an important goal to train professionals, moving all their skills, articulating several sets of knowledge and considering that their development is strongly linked to their quality of life ${ }^{(18)}$ and work. Thus, continuing education is recognized by some nurses as a tool to improve the quality of care provided to the users, as well as an instrument capable of contributing to reducing health costs and overloading in other levels of attention of the network.

\section{Conclusion}

The study revealed that the most frequent cause of hospitalizations in the area covered by the participating nurses is related to chronic diseases, which are among the ambulatory care sensitive conditions. Another finding was that, despite the intention to establish spaces for discussion and exchange of knowledge, the processes of continuing education developed by nurses are closer to the approach of continuous education with the transmission of new contents and updating of techniques. The interface between continuing education and ambulatory care sensitive conditions is still incipient and the way educational processes are developed does not favor an effective articulation to make continuing education, despite its great potential, to work more like a tool to support teams in the appropriate provision of care for these conditions.

\section{Collaborations}

Silva CEM and Friedrich DBC contributed to the drafting of the project, data collection, analysis and interpretation; writing of the manuscript and critical review of intellectual content; and final approval of the version to be published. Farah BF and Silva KL contributed to the relevant critical review of the intellectual content and in the approval of the final version to be published. 


\section{References}

1. Ministério da Saúde (BR). Secretaria de Atenção à Saúde. Departamento de Atenção Básica. Política nacional de atenção básica [Internet]. 2012 [citado 2017 set. 12]. Disponível em: http://189.28.128.100/dab/docs/publicacoes/ geral/pnab.pdf

2. Harrison MJ, Dusheiko M, Sutton M, Gravelle H, Doran T, Roland M. Effect of a national primary care pay for performance scheme on emergency hospital admissions for ambulatory care sensitive conditions: controlled longitudinal study. BMJ. 2014; 349:6423. doi: https://doi. org/10.1136/bmj.g6423

3. Franco CM, Koifman L. A concepção pedagógica problematizadora: uma didática para a educação permanente em saúde [Internet]. 2009 [citado 2017 maio 25 Disponível em: http://cdsa. aacademica.org/000-062/1563

4. Ministério da Saúde (BR). Secretaria de Gestão do Trabalho e da Educação na Saúde. Departamento de Gestão da Educação em Saúde. Política Nacional de Educação Permanente em Saúde [Internet]. 2009. [cited 2017 mar. 10]. Disponível em: http:// bvsms.saude.gov.br/bvs/publicacoes/politica nacional_educacao_permanente_saude.pdf

5. Minayo MCS. O desafio do conhecimento: pesquisa qualitativa em saúde. São Paulo: Hucitec; 2010.

6. Ministério da Saúde (BR). Portaria n. 221, de 17 de abril de 2008. Publica, na forma do anexo desta portaria, a lista brasileira de internações por condições sensíveis à atenção primária [Internet]. 2008 [citado 2017 mar. 12]; Disponível em: http://bvsms.saude.gov.br/bvs/saudelegis/ sas/2008/prt0221_17_04_2008.html

7. Borges PKO, Schawb PM, Blanski CR, Floriano LSM, Lopes BG, Muller EV. Sensitive hospitalizations to primary care and care in the health care network. Rev Rene. 2016; 17(5):668-75. doi: 10.15253/2175-6783.2016000500012

8. Rodrigues-Bastos RM, Campos EMS, Ribeiro LC, Firmino RUR, Bustamante-Teixeira MT. Hospitalizations for primary care-sensitive conditions in a Southern Brazilian municipality. Rev Assoc Med Bras. 2013;59(2):120-7. doi: http://dx.doi.org/10.1016/j.ramb.2012.11.001
9. Boing AF, Vicenzi RB, Magajewski F, Boing AC, Moretti-Pires RO, Peres KG et al. Redução das internações por condições sensíveis à atenção primária no Brasil entre 1998-2009. Rev Saúde Pública. 2012; 46(2):359-66. doi: http://dx.doi. org/10.1590/S0034-89102012005000011

10. Rodrigues-Bastos RM, Campos EMS, Ribeiro LC, Bastos Filho MG, Bustamante-Teixeira MT. Hospitalizations for ambulatory care-sensitive conditions, Minas Gerais, Southeastern Brazil, 2000 and 2010. Rev Saúde Pública. 2014;48(6):95867. doi: http://dx.doi.org/10.1590/S00348910.2014048005232

11. Freund T, Campbell SM, Geissler S, Kunz CU, Mabler C, Peters-Klimm F, et al. Strategies for reducing potentially avoidable hospitalizations for ambulatory care-sensitive conditions. Ann Fam Med. 2013; 11(4):363-70. doi: 10.1370/ afm.1498

12. Acioli S, Kebian LVA, Faria MGA, Ferraccioli P, Correa VAF. Práticas de cuidado: o papel do enfermeiro na atenção básica. Rev Enferm UERJ. 2014;22(5):637-42. doi: http://dx.doi. org/10.12957/reuerj.2014.12338

13. Ceccon RF, Meneghel SN, Viecili PRN. Hospitalization due to conditions sensitive to primary care and expansion of the Family Health Program in Brazil: an ecological study. Rev Bras Epidemiol. 2014; 17(4):968-77. doi: http:// dx.doi.org/10.1590/1809-4503201400040014

14. Van Loenen T, Van den Berg MJ, Westert GP, Faber MJ. Organizational aspects of primary care related to avoidable hospitalization: a systematic review. Fam Pract. 2014; 31(5):502-16. doi: 10.1093/fampra/cmu053.

15. Viana DMS, Nogueira CA, Araújo RS, Vieira RM, Rennó HMS, Oliveira VC. A educação permanente em saúde na perspectiva do enfermeiro na Estratégia de Saúde da Família. Rev Enferm Cent-Oeste Min [Internet]. 2015 [citado 2015 nov. 12];5(2):1658-68. Disponível em: http:// www.seer.ufsj.edu.br/index.php/recom/article/ view/470/868

16. Secretaria Municipal de Saúde (MG). Plano de saúde 2014-2017 [Internet]. 2013 [citado 2017 mar. 12]. Disponível em: https://www.pjf.mg.gov. br/conselhos/saude/documentos/plano_de_ saude_2014_2017_sspjf.pdf 
17. Mendes EV. O cuidado das condições crônicas na atenção primária à saúde: o imperativo da consolidação da estratégia da saúde da família [Internet]. 2012 [citado 2017 mar 12]. Disponível em:http://www.saude.go.gov.br/public/a/1lUN5 gHxOAAGWd/18446212121840542550.pdf

18. Salum NC, Prado ML. Continuing education in the development of competences in nurses. Texto Contexto Enferm. 2014; 23(2):301-8. doi: http://dx. doi.org/10.1590/0104-070720140021600011
19. Merhy EE. Educação permanente em movimento: uma política de reconhecimento e cooperação, ativando os encontros do cotidiano no mundo do trabalho em saúde, questões para os gestores, trabalhadores e quem mais quiser se ver nisso. Saúde Redes [Internet]. 2015 [citado 2017 mar 12];1(1):7-14. Disponível em: http://revista. redeunida.org.br/ojs/index.php/rede-unida/ article/view/309/15 